\title{
Synthesis of Halicylindramide A Mimetics Containing Lactone Isosteres ${ }^{\dagger}$
}

\author{
Sanghyuk Yeo, Hyunju Seo, and Dongyeol Lim* \\ Department of Chemistry, Sejong University, Seoul 143-747, Korea.*E-mail: dylim@sejong.ac.kr \\ Received January 14, 2011, Accepted February 8, 2011
}

\begin{abstract}
Synthesis of halicylindramide A mimetics via solid-phase peptide synthesis is described. The $N$-Me-Gly-Thr residues in halicyclindramide A has been replaced by $N$-Me-Gly-Dpr, Lys, or $N$-Me-Gly-allo-Thr. Solution structures of the mimetics were compared by CD spectroscopy in an aqueous buffer and in TFE.
\end{abstract}

Key Words : Synthesis, Halicylindramide A, Mimetic, Depsipeptide

\section{Introduction}

Halicylindramides $\mathrm{A}-\mathrm{D}^{1}$ are cyclodepsipetides of marine origin with potent antifungal and cytotoxic activities. These molecules are amphiphilic and share many unusual amino acids, such as D-amino acids, $N$-methyl amino acids, and cysteic acid, and contain a formyl-D-Ala residue at the $N$ terminus (Figure 1). Other cyclic depsipeptides, such as discodermins $\mathrm{A}-\mathrm{H},{ }^{2}$ polydiscamide $\mathrm{A}-\mathrm{D},{ }^{2 \mathrm{~b}, 3}$ microspinosamide, ${ }^{2 \mathrm{c}}$ and corticiamide $\mathrm{A}^{4}$ have also been isolated from marine sponges, and they possess unusual amino acids such as those found in halicylindramides. Notably, the presence of Dcysteic acid is a unique characteristic, shared only by these depsipeptides.

These peptides possess various activities, such as antimicrobial, anticancer, and anti-HIV-1 activities, and are known to interact with phospholipase $A_{2}$ or $G$ protein-coupled receptor (GPCR). Although the conformations and modes of action of these peptides have yet to be elucidated, their activities appear to be related to their association with membrane proteins as a result of their amphiphilic character. Increased membrane permeabilization of $\mathrm{Ca}^{2+}$ and ATP by

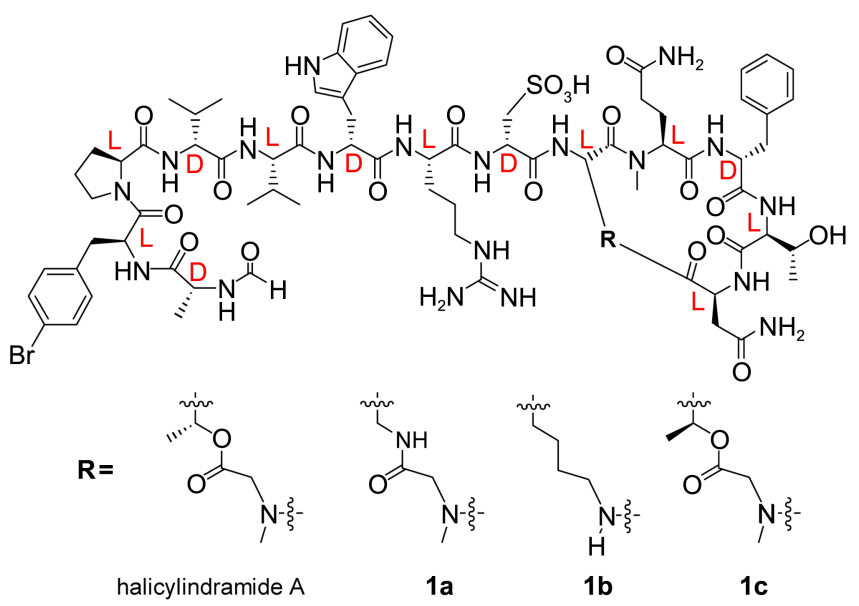

Figure 1. Structure of halicylindramide A and its mimetics.

This paper is dedicated to Professor Eun Lee on the occasion of his honourable retirement. discodermin A was reported in 2001. ${ }^{5}$

In 2009, we reported the first synthesis of halicylindramide $A$ and its conformational change by a CD study in a membrane environment. ${ }^{6}$ However, no other depsipeptides containing D-cysteic acid have been synthesized to date. In this paper, we describe a solid-phase synthesis of halicylindramide A mimetics where the $N$-Me-Gly-Thr, the ester linkage of the cyclic part, is replaced by $N$-Me-Gly-Dpr, Lys, or $N$ Me-Gly-allo-Thr (Figure 1). A preliminary conformational study by CD spectroscopy was also performed.

Conformational restriction imposed by ring formation is known to be important for activity and stability and is often adopted in peptidomimetic studies. Syntheses of halicylindramide mimetics containing lactone isosteres would therefore be valuable in exploring halicylindramide conformational changes and in understanding the mechanism of the membrane interactions of these peptides.

\section{Results and Discussion}

For the syntheses of mimetics of halicylindramide A, we applied the same strategy as we used for the synthesis of halicylindramide A. ${ }^{6}$ So, Rink amide resin was anchored to the side chain of the Asp residue and macrolactamization was performed on the resin. After coupling of all the amino acids, oxidation of the resin-bound Cys residue was carried out and, after the resin cleavage, the last step was formylation of the $N$-terminal Ala residue.

The resin-bound peptide $\mathbf{2}$ was prepared as in the previous synthesis of halicylindramide A (Scheme 1). To synthesize the amide mimetic 1a, we incorporated Fmoc-Dpr(Mtt)-OH to provide 3. The side chain of the amino acid Dpr should be protected with a 4-methyltrityl (Mtt) group, which can be selectively removed under mild acidic conditions to enable coupling of further amino acids. The Mtt group of the Dpr residue was removed under $1 \%$ TFA, and then a free amino group was coupled to Alloc-Sar-OH to yield the resin-bound peptide 4. The Alloc and allyl protecting groups at the Sar and Asn residues were removed selectively by treatment with $\mathrm{Pd}\left(\mathrm{Ph}_{3} \mathrm{P}\right)_{4}{ }^{7}$. The deprotected peptide was then cyclized between the Sar and Asn residues with an excess of a HATU/ HOAt/NMM mixture, providing the resin-bound cyclic peptide 


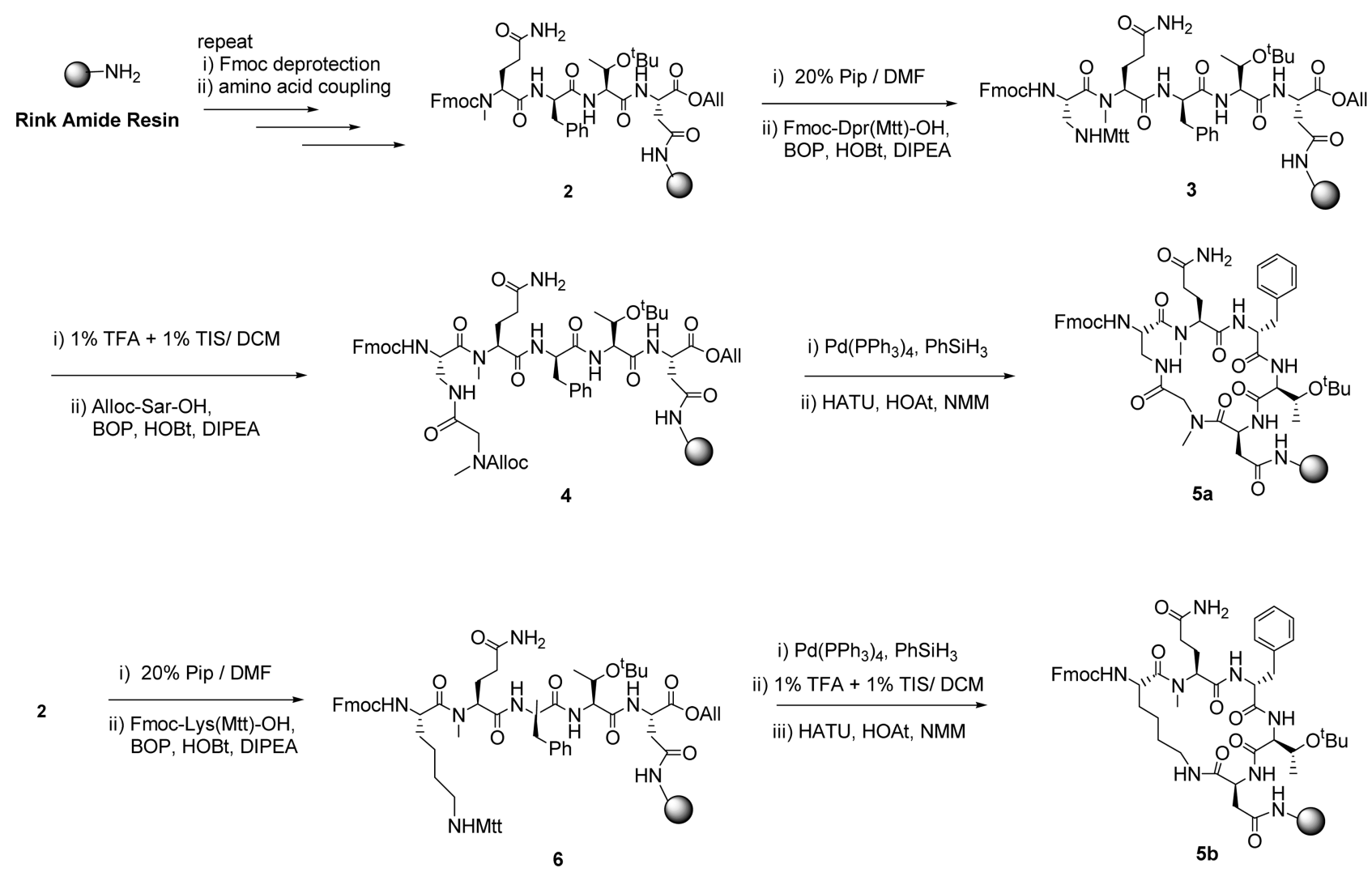

Scheme 1. Synthesis of $\mathbf{5 a}$ and $\mathbf{5 b}$.
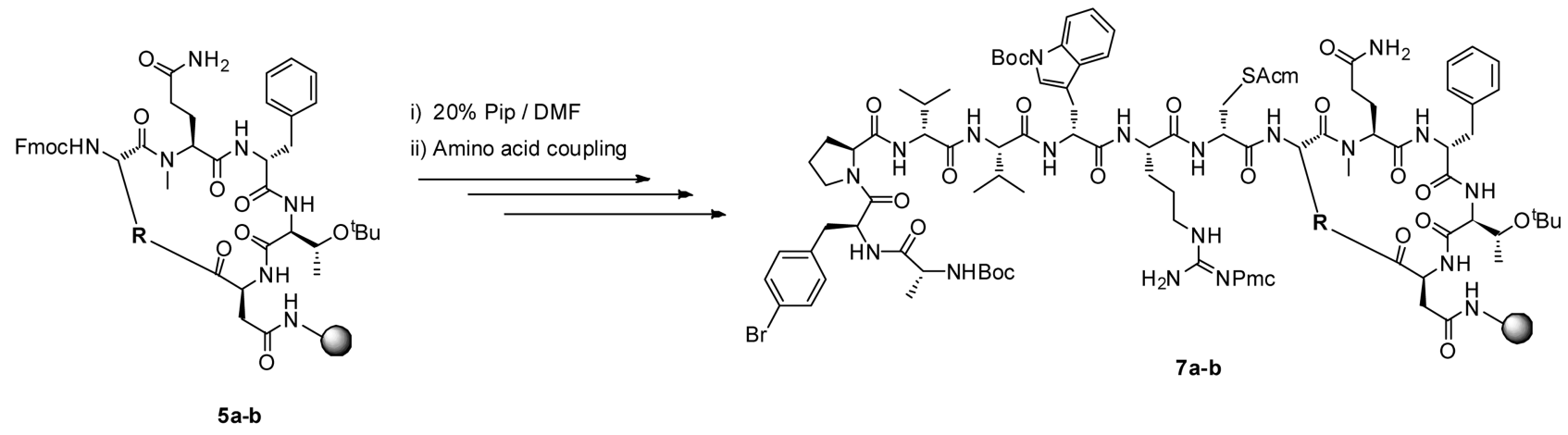

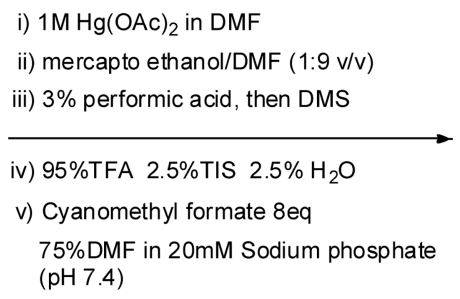

i) $1 \mathrm{MHg}(\mathrm{OAc})_{2}$ in $\mathrm{DMF}$

mercapto ethanol/DMF $(1.9 \mathrm{~V} / \mathrm{V})$

iv) $95 \%$ TFA $2.5 \%$ TIS $2.5 \% \mathrm{H}_{2} \mathrm{O}$ $(\mathrm{pH} 7.4)$

Scheme 2. Synthesis of 1a-b

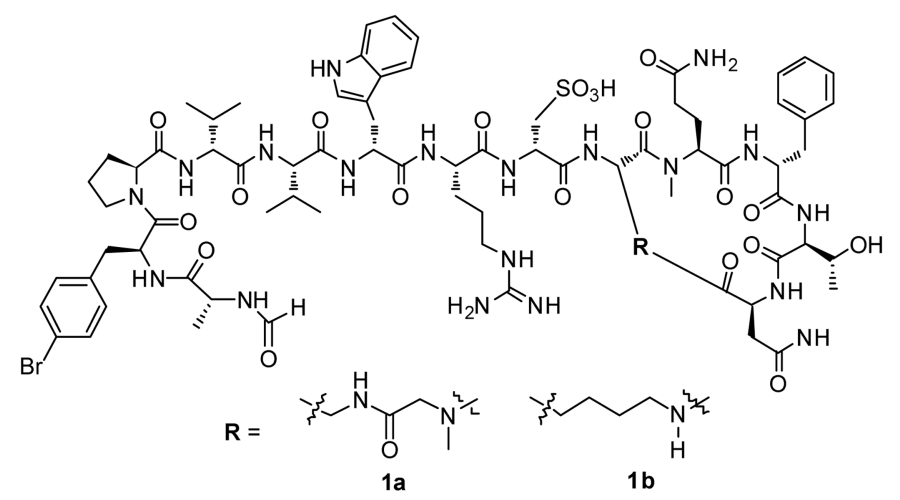


5a. The cyclization reaction was assessed using the chloranil test to detect the absence of the secondary amine of the Sar residue. $^{8}$

For the preparation of $\mathbf{5} \mathbf{b}$, an alkane mimetic of halicylindramide A, Fmoc-Lys(Mtt)-OH was used to provide the peptide 6. The allyl and Mtt protecting groups were removed selectively by employing the same deprotection conditions as for the synthesis of $\mathbf{5 a}$, and the resulting peptide was then cyclized to obtain the resin-bound peptide 6a.

The cyclic peptides 5a-b were further elongated one by one with the remaining $N$-terminal amino acids, using PyBOP/ HOAt/DIPEA to afford compounds 7a-b (Scheme 2). Coupling of the D-Cys analog was performed while the side chain of the Cys residue was protected with an acetamidomethyl $(\mathrm{Acm})$ group, which can be removed selectively and oxidized to cysteic acid. When we attempted segment coupling of the $N$-terminal peptide onto $\mathbf{5 a}$, no coupled product could be obtained after resin cleavage.

The indole ring of the Trp residue can be easily oxidized to form various byproducts under oxidative conditions. ${ }^{9}$ Hence, the Cys residue was oxidized while the Trp residue was protected with a Boc group in the solid phase. The resin was treated with $1 \mathrm{M} \mathrm{Hg}(\mathrm{OAc})_{2}{ }^{10}$ in DMF to deprotect the Acm group selectively from the Cys residue and washed with $10 \%$ mercaptoethanol to remove $\mathrm{Hg}^{2+}$ ions (Scheme 2). The free thiol was then oxidized with freshly prepared $3 \%$ performic acid ${ }^{11}$ and the resin was treated with dimethylsulfide

(a)

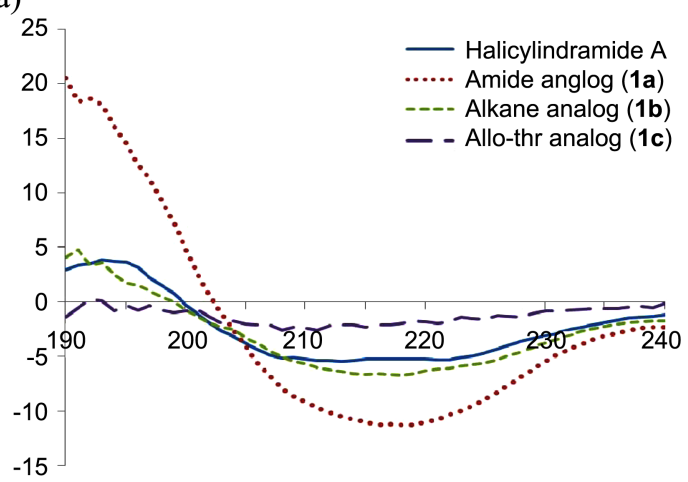

(b)

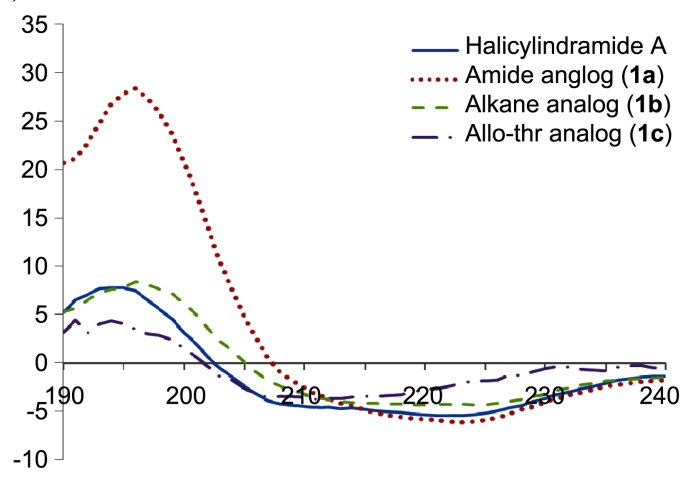

Figure 2. Comparison of CD spectra of 1a-c and halicylindramide $\mathrm{A}$ in (a) aqueous buffer and (b) TFE. to remove excess oxidant. The oxidized cyclic peptide from the performic acid oxidation was cleaved from the resin and purified by RP-HPLC to provide two deformyl mimetics of halicylindramide A.

Finally, the $N$-terminal Ala residue was formylated using an excess of cyanomethyl formate ${ }^{12}$ in a solution of DMFsodium phosphate buffer ( $\mathrm{pH}$ 7.4) at room temperature. The crude product was purified by semipreparative RP-HPLC to give 1a-b. The pure peptides $\mathbf{1 a - b}$ were analyzed by ${ }^{1} \mathrm{H}$ and 2D NMR, HRMS, CD, and analytical RP-HPLC.

For the synthesis of 1c, an allo-Thr derivative of halicylindramide $\mathrm{A}$, we followed the same strategy for the synthesis of halicylindramide A.

CD spectra of 1a-c and halicylindramide A were examined to compare their conformations under different conditions (Figure 2). The overall conformation of $\mathbf{1 b}$ is fairly similar to that of halicylindramide $\mathrm{A}$ in both an aqueous buffer and in trifluoroethanol (TFE). However, for peptide 1a in an aqueous buffer, stronger intensities were observed at both the negative absorption around $220 \mathrm{~nm}$ and the maximum below $200 \mathrm{~nm}$, while only the negative peak was intensified in TFE. The stronger absorptions suggest that the amide group in 1a forces the molecule to adopt a more stable secondary structure than that produced by the ester and alkane groups in $\mathbf{1 b}$ and 1c, respectively. This is probably due to the presence of additional H-bonding interaction(s) in 1a. For the allo-Thr analog 1c, much weaker intensities were observed in both solvents.

\section{Conclusions}

In summary, we demonstrated the synthesis of three mimics of halicylindramide A via solid-phase peptide synthesis. The ester linkage between the side-chain of Thr and Sar in halicyclindramide A was replaced by an ester with a different stereochemistry at the Thr residue, an amide, and an alkane. Their solution structures were compared using CD spectroscopy in an aqueous buffer and in TFE. The CD spectra suggested that the amide analog 1a could adopt a more stable secondary structure, while the structure of the alloThr analog 1c was less restricted in both solvents. The conformational stability of $1 \mathbf{a}$ was induced via intramolecular $\mathrm{H}$-bonding interaction(s) of the additional amide linkage and may alter its biological activity greatly by changing the mode of ligand-receptor interaction(s).

\section{Experimental Section}

General. All reagents were obtained from commercial suppliers and used without further purification, unless specified. ${ }^{1} \mathrm{H}$ and ${ }^{13} \mathrm{C}$ NMR spectra were collected on a Bruker UI500 spectrometer at resonance frequencies of $500.1 \mathrm{MHz}$ and 125.7 MHz, respectively. The solvents used were DMSO$d^{6}$ and $\mathrm{CD}_{3} \mathrm{OD}$. The chemical shifts are reported in ppm from tetramethylsilane or referenced to the solvent on the $\delta$ scale. LRMS (ESI) and HRMS (ES $\left.{ }^{+}\right)$spectra were recorded on an Agilent 1100 LC/MSD and a Micromass LCT, 
respectively. Analytical RP-HPLC was carried out using a Kromasil 100-5C18 $(4.6 \times 150 \mathrm{~mm})$ reverse-phase column at a flow rate of $1.0 \mathrm{~mL} / \mathrm{min}$ with UV detection at $215 \mathrm{~nm}$ and $254 \mathrm{~nm}$. Linear gradients of $\mathrm{CH}_{3} \mathrm{CN}-\mathrm{H}_{2} \mathrm{O}$ solvents, each containing $0.5 \%$ TFA, were used as follows: conditions A (5-100\% $\mathrm{CH}_{3} \mathrm{CN}$ over $20 \mathrm{~min}$ ), and conditions B (30-45\% $\mathrm{CH}_{3} \mathrm{CN}$ over $20 \mathrm{~min}$ ). For semipreparative HPLC, a Vydac C18 column $(5 \mu \mathrm{m}, 10 \times 150 \mathrm{~mm}, 218 \mathrm{TP} 510)$ was employed at a flow rate of $3.0 \mathrm{~mL} / \mathrm{min}$ using gradient conditions B.

Peptide Synthesis. Peptide synthesis was accomplished manually via stepwise solid-phase synthesis using Fmoc chemistry. Reaction completion was determined using qualitative Kaiser ${ }^{13}$ or chloranil tests ${ }^{14}$. Washings between deprotection and coupling were carried out with DMF $(7 \times 3$ min) and $\mathrm{CH}_{2} \mathrm{Cl}_{2}(3 \times 3 \mathrm{~min})$ using $10 \mathrm{~mL}$ solvent/g resin for each treatment. After removal of the Fmoc group from the Rink amide resin (500 mg, $0.375 \mathrm{mmol}, 100-200$ mesh, 1\% DVB, $0.75 \mathrm{mmol} / \mathrm{g}$ ), coupling of the amino acids was achieved by shaking the resin in a solution of Fmoc amino acids, 4 equiv of PyBOP $(781 \mathrm{mg}), 4$ equiv of $\mathrm{HOBt}(230$ $\mathrm{mg}$ ) or HOAt $(204 \mathrm{mg})$, and 6 equiv of DIPEA $(0.37 \mathrm{~mL})$ in DMF $(3 \mathrm{~mL})$ for $1 \mathrm{~h}$ at room temperature. An excess of amino acids [2 equiv for the coupling of Asp, $\operatorname{Thr}(\mathrm{t}-\mathrm{Bu})$, DPhe, $(N-\mathrm{Me}) \mathrm{Gln}, \mathrm{Dpr}(\mathrm{Mtt})$, Lys(Mtt) and D-Cys(Acm) derivatives and 3 equiv for $\operatorname{Arg}(\operatorname{Pmc})$, D-Trp(Boc), Val, DVal, Pro, (Br)Phe, and D-Ala derivatives] was used. The Fmoc group was removed using $20 \%(\mathrm{v} / \mathrm{v})$ piperidine in DMF $(3 \times 5 \mathrm{~min})$.

The Mtt groups in the Dpr and Lys residues were removed by treating the resin with a $\mathrm{CH}_{2} \mathrm{Cl}_{2}$ solution of TFA and TIS ( $1 \%$ each, $10 \times 5 \mathrm{~min}$ ). Introduction of the Sar residue to the side chain of the Dpr residue was achieved under general conditions using a solution of Alloc-Sar-OH (2.0 equiv), PyBOP (2.5 equiv.), HOBt (2.5 equiv.), and DIPEA (4 equiv.). The Alloc and allyl protecting groups were removed by shaking the resin with 0.1 equiv. of $\mathrm{Pd}\left(\mathrm{PPh}_{4}\right)_{4}$ and 12 equiv. of $\mathrm{PhSiH}_{3}$ in $\mathrm{CH}_{2} \mathrm{Cl}_{2}(4 \mathrm{~mL})$ under a nitrogen atmosphere for $4 \mathrm{~h}$. The chloranil test was positive, indicating the presence of the secondary amine of the Sar residue.

The cyclization step was carried out using 5 equiv of $N$ methyl morpholine $(0.21 \mathrm{~mL}, 1.88 \mathrm{mmol}), 5$ equiv of HATU (713 mg, $1.88 \mathrm{mmol}$ ), and 1 equiv of HOAt (51 mg, 0.375 $\mathrm{mmol}$ ) in DMF (3 mL). After shaking overnight, a negative chloranil test result was obtained. A small portion of the resin was cleaved with TFA- $\mathrm{CH}_{2} \mathrm{Cl}_{2}(1: 1)$ and the crude product was analyzed by RP-HPLC. Deprotection of $S$-Acm was performed by treatment with $1 \mathrm{M} \mathrm{Hg}(\mathrm{OAc})_{2}$ in DMF ( $\mathrm{pH} \mathrm{4}$, adjusted with a few drops of acetic acid) for $3 \mathrm{~h}$ in darkness. The resin was washed with DMF $(3 \times 3 \mathrm{~min})$ and $\beta$-mercaptoethanol-DMF $(1: 9,3 \times 3 \mathrm{~min})$ to remove $\mathrm{Hg}^{2+}$ from the resin-bound peptide. A small portion of the resin was cleaved as above and the crude product was analyzed by RP-HPLC.

Oxidation of Cys. A performic acid (3\%) solution was prepared by mixing 35\% hydrogen peroxide and $98 \%$ formic acid $(8: 92, \mathrm{v} / \mathrm{v})$, and the solution was allowed to stand at room temperature for $1 \mathrm{~h}$. The free thiol of the Cys residue was treated with freshly prepared $3 \%$ performic acid $(5 \mathrm{~mL})$ in a bath at $0{ }^{\circ} \mathrm{C}$ for $2 \mathrm{~h}$ under a nitrogen atmosphere. Dimethyl sulfide $(0.4 \mathrm{~mL})$ was added to the reaction mixture and the solution was left to stand for $10 \mathrm{~min}$ to quench the excess oxidants. A small portion of the resin was cleaved and the crude product was analyzed by RP-HPLC.

Peptide Cleavage and Isolation. The resin-bound peptide was washed thoroughly with DMF $(10 \times 3 \mathrm{~min})$ and $\mathrm{CH}_{2} \mathrm{Cl}_{2}$ $(5 \times 3 \mathrm{~min})$, and then dried in vacuo overnight. The peptide was removed from the solid support using TFA containing $2.5 \%(\mathrm{v} / \mathrm{v}) \mathrm{i}-\mathrm{Pr}_{3} \mathrm{SiH}$ and $2.5 \%(\mathrm{v} / \mathrm{v}) \mathrm{H}_{2} \mathrm{O}$ for $2 \mathrm{~h}$ at room temperature. This cleavage step was repeated three times, and the combined solution was concentrated to $\sim 2 \mathrm{~mL}$ under reduced pressure. Cold diethyl ether was added to the solution and the precipitated peptide was filtered and dried to obtain the crude analogs. HPLC and mass spectrometry analyses of the crude product indicated that the major peak was the desired peptide. The crude peptides were dissolved in $\mathrm{MeOH}$ and allowed to stand for $2 \mathrm{~d}$ at room temperature. After purification by semipreparative RP-HPLC, pure products were obtained as white solids.

The deformyl amide analog: $33 \mathrm{mg}, 5 \%$ overall yield from the starting resin $(500 \mathrm{mg})$; HRMS $\left(\mathrm{ES}^{+}\right)$calcd for $\mathrm{C}_{76} \mathrm{H}_{107} \mathrm{BrN}_{21} \mathrm{Na}_{2} \mathrm{O}_{20} \mathrm{~S} \quad[\mathrm{M}+2 \mathrm{Na}-\mathrm{H}]^{2+}$ 897.3424, found 897.3483. Analytical RP-HPLC (condition B): $R_{\mathrm{t}}=12.7 \mathrm{~min}$.

The deformyl alkane analog: $9 \mathrm{mg}, 3 \%$ overall yield from the starting resin $(230 \mathrm{mg})$; HRMS $\left(\mathrm{ES}^{+}\right)$calcd for $\mathrm{C}_{76} \mathrm{H}_{109} \mathrm{BrN}_{20} \mathrm{NaO}_{19} \mathrm{~S}[\mathrm{M}+\mathrm{Na}]^{2+}$ 871.8564, found 871.8555. Analytical RP-HPLC (conditions $30-65 \% \mathrm{CH}_{3} \mathrm{CN}$ over 20 $\min ): R_{\mathrm{t}}=9.0 \mathrm{~min}$.

The deformyl allo-Thr analog: $10 \mathrm{mg}, 1.5 \%$ overall yield from the starting resin $(500 \mathrm{mg})$; Analytical RP-HPLC (conditions B): $R_{\mathrm{t}}=14.6$ min.

Formylation. Formylation of the $N$-terminal Ala residue of 1a-c using cyanomethyl formate was performed using a minor modification of the method of Deutsch and Niclas. ${ }^{15}$ Each deformyl analog was dissolved in $1.5 \mathrm{~mL}$ of $75 \% \mathrm{DMF}$ in $\mathrm{H}_{2} \mathrm{O}$ containing sodium phosphate buffer $(20 \mathrm{mM}, \mathrm{pH}$ 7.4). Cyanomethyl formate (10 equiv.) was added to this solution and the mixture was allowed to stand at room temperature for several days in darkness. The reactions were monitored by analytical RP-HPLC and the crude products were purified by semipreparative RP-HPLC to give 1a-c as white solids. The ${ }^{1} \mathrm{H}$ NMR and 2D NMR (COSY, ROESY, TOCSY, HMBC, and HSQC) data for 1a-c were obtained, and their NMR data are listed in the supporting information.

The amide analog (1a): $13.5 \mathrm{mg}(90 \%$ yield based on HPLC analysis); HRMS (ES ${ }^{+}$calcd for $\mathrm{C}_{77} \mathrm{H}_{108} \mathrm{BrN}_{21} \mathrm{Na}_{2} \mathrm{O}_{21} \mathrm{~S}$ $\left[\mathrm{M}+\mathrm{Na}_{2}\right]^{2+}$ 911.8438, found 911.8446. Analytical RP-HPLC (conditions B): $R_{\mathrm{t}}=14.3 \mathrm{~min}$.

The alkane analog (1b): $6.8 \mathrm{mg}$ (75\% yield); HRMS (ES $)$ calcd for $\mathrm{C}_{77} \mathrm{H}_{110} \mathrm{BrN}_{20} \mathrm{NaO}_{20} \mathrm{~S}[\mathrm{M}+\mathrm{H}+\mathrm{Na}]^{2+}$ 886.3578, found 886.3517. Analytical RP-HPLC (conditions A): $R_{\mathrm{t}}=$ $13.2 \mathrm{~min}$.

The allo-Thr analog (1c): $6 \mathrm{mg}$ (60\% yield); HRMS (ES $\left.{ }^{+}\right)$ calcd for $\mathrm{C}_{78} \mathrm{H}_{109} \mathrm{BrN}_{20} \mathrm{Na}_{2} \mathrm{O}_{22} \mathrm{~S}\left[\mathrm{M}+\mathrm{Na}_{2}\right]^{2+}$ 919.3437, found 919.3119. Analytical RP-HPLC (conditions B): $R_{\mathrm{t}}=15.1 \mathrm{~min}$. 
CD Measurements. CD experiments were performed at room temperature using a Jasco 715 spectropolarimeter with a path length of $1.0 \mathrm{~cm}$. Each sample was dissolved in TFE or sodium phosphate buffer (20 mM, pH 7.4) to give a 100 $\mu \mathrm{M}$ concentration. Data were collected from $260 \mathrm{~nm}$ to 190 $\mathrm{nm}$ in $1-\mathrm{nm}$ increments at a scan rate of $20 \mathrm{~nm} / \mathrm{min}$ and a 3-s signal averaging time.

Acknowledgments. This research was supported by grants from the Basic Science Research Program through the National Research Foundation of Korea (NRF) funded by the Ministry of Education, Science and Technology (20090077608) and Marine Biotechnology Program funded by the Ministry of Land, Transport and Maritime Affairs, Republic of Korea. HRMS (ESI) data were obtained using the facilities of the Korea Basic Science Institute.

\section{References}

1. (a) Li, H.-Y.; Matsunaga, S.; Fusetani, N. J. Med. Chem. 1995, 38, 338-343. (b) Li, H.-Y.; Matsunaga, S.; Fusetani, N. J. Nat. Prod. 1996, 59, 163-166.

2. (a) Matsunaga, S.; Fusetani, N.; Konosu, S. Tetrahedron Lett. 1984, 25, 5165-5168. (b) Matsunaga, S.; Fusetani, N.; Konosu, S. J. Nat. Prod. 1985, 48, 236-241. (c) Matsunaga, S.; Fusetani, N.;
Konosu, S. Tetrahedron Lett. 1985, 26, 855-856. (d) Ryu, G.; Matsunaga, S.; Fusetani, N. Tetrahedron Lett. 1994, 35, 82518254. (e) Ryu, G.; Matsunaga, S.; Fusetani, N. Tetrahedron 1994, 50, 13409-13416.

3. Feng, Y.; Carroll, A. R.; Pass, D. M.; Archbold, J. K.; Avery, V. M.; Quinn, R. J. J. Nat. Prod. 2008, 71, 8-11.

4. Laird, D. W.; LaBarbera, D. V.; Feng, X.; Bugni, T. S.; Harper, M. K.; Ireland, C. M. J. Nat. Prod. 2007, 70, 741-746.

5. Sato, K.; Horibe, K.; Amano, K.-i.; Mitusi-Saito, M.; Hori, M.; Matsunaga, S.; Fusetani, N.; Ozaki, H.; Karaki, H. Toxicon. 2001, 39, 259-264.

6. Seo, H.; Lim, D. The Journal of Organic Chemistry 2009, 74, 906-909.

7. Guibé, F. Tetrahedron 1998, 54, 2967-3042.

8. Vojkovsky, T. Pept. Res. 1995, 8, 236-237.

9. Matthiesen, R.; Bauw, G.; Welinder, K. G. Anal. Chem. 2004, 76, 6848-6852.

10. Greene, T. W.; Wuts, P. G. M. Protecting Groups in Organic Synthesis, 3rd ed.; John Wiley \& Sons: New York, 1999; Vol. II.

11. Hirs, C. H. W. In Methods in Enz.; Hirs, C. H. W., Ed.; Academic Press: New York, 1967; pp 197-199.

12. Deutsch, J.; Niclas, H.-J. Synthetic Commun. 1993, 23, 15611568.

13. Kaiser, E.; Colescott, R. L.; Bossinger, C. D.; Cook, P. I. Anal. Biochem. 1970, 34, 595-598.

14. Vojkovsky, T. Pept. Res. 1995, 8, 236-237.

15. Deutsch, J.; Niclas, H.-J. Synthetic Commun. 1993, 23, 15611568 . 